\title{
Research on the Information of Teaching Management in Colleges and Universities
}

\author{
Liping Yin \\ School of Humanities, Jilin Agricultural University, Changchun 130118, China \\ 5289977@qq.com
}

\begin{abstract}
With the vigorous development of China's higher education and the deepening of the reform of higher education, all Colleges and universities pay more attention to the important influence of teaching management on the quality of personnel training. In order to enhance the teaching management level and improve work efficiency, Chinese Colleges and universities have introduced computer, network communication and other modern information technologies into the teaching management, exploring teaching management information construction in Colleges and universities. This paper introduces the meaning of teaching management information, and through the analysis of the current situation of teaching management in Colleges and universities, and finally puts forward the development countermeasures.
\end{abstract}

Keywords: College teaching; Information; Management.

\section{An Overview of Teaching Management Information in Colleges and Universities}

\subsection{Connotation of Teaching Management Information in Colleges and Universities}

College teaching management information is derived from information management thought in the field of higher education management. It refers to the state and method of, under the guidance of modern education thought, making use of modern information technology like computer, network communication and multimedia to manage the teaching process in Colleges and universities, so as to achieve the teaching goal, which is the specific application of information technology in the field of education management in Colleges and universities. College teaching management information, based on advanced information technology, according to modern higher education and management thoughts, changes the traditional teaching management mode, through the efficient implementation of the teaching process plan, organization, command, coordination, and control to achieve the teaching goal of higher school. College teaching management information system not only means the development and construction of the related hardware and software platform of university teaching management information system, but also includes the modernization, scientific orientation and efficiency of teaching management concept.

\subsection{Related Theories of Teaching Management Information in Colleges and Universities (table}

\section{1 and table 2)}

\section{Current Situation of Information Construction of Teaching Management in Colleges and Universities in China}

In twenty-first Century, in order to adapt to the rapid development of China's higher education and the gradual promotion of the teaching reform of the credit system, Colleges and universities have introduced computer, network communication and other modern information technologies into the teaching management, and on the road of improving the teaching management level and the efficiency of the teaching management, strive to explore teaching management information construction [1].

From the overall situation of the implementation of our Colleges and universities teaching management information, restricted by the teachers, the field and laboratory and other basic running conditions, the complete credit system in the teaching management of Colleges and universities in China is still in the exploratory stage at present [2]. The majority of our Colleges and universities have not yet implemented a complete credit system, what is actually implemented is teaching 
management mode of the credit system, in the transition stage to the complete credit system, so the teaching management information construction in most Colleges and universities in our country at present is based on this mode of teaching management.

Table 1 Educational theory

\begin{tabular}{|c|c|c|c|c|}
\hline \multicolumn{5}{|c|}{ Educational theory } \\
\hline $\begin{array}{c}\text { Research } \\
\text { object }\end{array}$ & Research problems & $\begin{array}{c}\text { Research } \\
\text { basis }\end{array}$ & Research purpose & Features \\
\hline $\begin{array}{l}\text { Educational } \\
\text { issue }\end{array}$ & $\begin{array}{l}\text { To sum up the scientific theory } \\
\text { and practice of human } \\
\text { educational activities, to explore } \\
\text { and solve practical problems } \\
\text { encountered in the course of the } \\
\text { development of educational } \\
\text { activities. }\end{array}$ & $\begin{array}{l}\text { Educational } \\
\text { fact }\end{array}$ & $\begin{array}{l}\text { Explore and reveal } \\
\text { the regularity of } \\
\text { educational activities, } \\
\text { in order to serve the } \\
\text { educational practice. }\end{array}$ & $\begin{array}{l}\text { Objectivity, } \\
\text { inevitability, stability, } \\
\text { repetitiveness, reality, } \\
\text { dialectical, and } \\
\text { scientific orientation }\end{array}$ \\
\hline
\end{tabular}

Table 2 Management theories

\begin{tabular}{|c|c|c|}
\hline \multicolumn{3}{|c|}{ Management theories } \\
\hline Scientific management theory & Interpersonal relationship theory & Behavioral science theory \\
\hline $\begin{array}{l}\text { Scientific management theory } \\
\text { is the earliest management } \\
\text { thought in twentieth Century, } \\
\text { which takes efficiency as the } \\
\text { core. }\end{array}$ & $\begin{array}{l}\text { The influence of interpersonal } \\
\text { relationship theory on the field of } \\
\text { education management is mainly } \\
\text { reflected in the introduction of the } \\
\text { idea of democratic management into } \\
\text { the management of education and } \\
\text { focusing on the various social and } \\
\text { psychological needs. }\end{array}$ & $\begin{array}{l}\text { Behavioral science theory provides a } \\
\text { multi-dimensional perspective for } \\
\text { education management; it emphasizes } \\
\text { the empirical research of educational } \\
\text { management; it proposes that the school } \\
\text { is taken as an open system in the research } \\
\text { of educational management. }\end{array}$ \\
\hline
\end{tabular}

From the point of view of overall running state of the construction of teaching management information, currently the majority of Colleges and universities teaching management departments have adopted the teaching management information system to carry out computer network management on the key links of teaching management work, and gradually realize the centralized management of large amounts of data in the teaching process [3]. With the gradual promotion of teaching management's information, the management process of teaching management department has become increasingly standardized. Since that the computer software system has completed a considerable part of the work, it to a large extent reduces the labor intensity of the teaching management, and makes the teaching management staffs gradually pay more attention to the macro management and monitoring of teaching effect in the teaching process, and the teaching management level, compared with the previous manual mode operation, has been greatly improved [4]. However, most of the Colleges and universities constraint by management mode, hardware resources and other factors, although the information of teaching management is carried out, the sub-systems of the management system cannot achieve effective docking or provide comprehensive information consulting services, forming more "information island", so the teaching management information level remains to be further improved.

\section{Problems in Information Construction of Teaching Management in Colleges and Universities in China}

At the present stage, although a small part of the "985", "211" College teaching management information construction has achieved good results, the teaching management information is in a higher level. But the majority of Colleges and universities in the process of promoting the information of teaching management, there are still many backward teaching information 
management concepts, without fully understanding the connotation of information, which restricts the further development of the teaching management information. Combining the analysis of the current situation of China's College teaching management information popularization, construction of Colleges and universities, and the summary of existing research results, the author thinks that there are the problems existing in the construction of teaching management information.

\subsection{Deviation of the Understanding of Teaching Management Information}

At present, many Colleges and universities in our country have a deviation in understanding the connotation of teaching management information, simple and one-sided. Their understanding of the teaching management information technology level is only remained in the technology level of the implemented teaching management information, ignoring the leading role of the modern scientific teaching management concept in teaching management information construction. The development and construction of teaching management information system hardware and software platform is an important basic work in the concrete implementation process of teaching management information. But many Colleges and universities carry out the development and construction of the hardware platform of teaching management information system on the conditions that they are unclear about "Why do we carry out information?" "How to carry out information" these global issues.

\subsection{Poor Guarantee of Material Conditions of Teaching Management Information Construction}

The implementation basis of teaching management information is the construction of teaching management information system and teaching information resources, and the operation of the information system needs the perfect hardware and software platform to support. To develop the relevant configuration platforms, schools need to invest a lot of money, manpower and material resources as material guarantee for teaching management information construction.

Many universities in our country, in order to cope with the enrollment, massively expand the scale for many years, invest a considerable money in the student dormitories, canteens, other buildings and related infrastructure projects, crowding out a large number of valuable financial and material resources, making the funds for the school to carry out teaching management information construction more limited. It leads to that many Colleges and universities, in the implementation process of teaching management information, there are good ideas and thought of construction planning, but suffers from a lack of material security and thus results in that the demand of teaching management information construction is difficult to put into practice. On the other hand, although many Colleges and universities also allocate special funds of teaching management information construction, it still lacks a reasonable allocation of funds to do the overall consideration in the construction of teaching management information, implementing average distribution in the allocation of funds, no prominent key nodes or key areas.

\subsection{Lack of Extensive Participation in Teaching Management Information Construction}

Teaching management information construction is the overall work related to the teaching management and teaching services, whose impact is huge, involving all aspects of the work of teaching and management in Colleges and universities. Many universities in China in the process of teaching management information, the division of responsibilities between the relevant departments is not clear and lack effective cooperation and coordination between each other, the enthusiasm for the construction of teaching management information of two level departments in school is not high, and implementation of related work is inadequate, bringing obstacles for the implementation of this work [5]. On the other hand, although some universities have already completed the research and development of hardware and software platform of the teaching management information system, in the process of further promoting application, advanced technology solutions have not reached the expected effect, so teaching management information system often turns into internal system used in a small number of teaching management departments. 


\section{Countermeasures and Suggestions on the Improvement of Teaching Management Information Construction in Colleges and Universities}

\subsection{Significance of Strengthening Teaching Management Information}

In order to construct and develop information technology, updating the concept should go ahead, and it is necessary to correctly understand the connotation of teaching management information and strengthen the understanding of the significance of teaching management information. College teaching management information refers to the full use of teaching management thoughts, methods and means and information technology to carry out modern education management, thus improving the quality and efficiency of teaching management and realizing the modernization of teaching management.

\subsection{Perfect Information Construction Organization and Highlight the Top-level Design}

The implementation and promotion of any important work should be supported by a perfect leading organizational institution. The construction of teaching management information in Colleges and universities is the systematic work that is related to teaching and personnel cultivation, which needs the collaboration of relevant departments, the second level departments to actively implement the teaching, and the teaching management staffs widely participate in.

\subsection{Perfect Teaching Management Information System}

Some Colleges and universities of China invest a lot in the construction of teaching management information system in the process of teaching management information construction, but the related system is relatively insufficient, resulting in not standard use of information system operation, damaging the reality and effectiveness of teaching operation data, and affecting the operation effectiveness of teaching management information system. Therefore, it is necessary to perfect the relevant systems of the teaching management information in teaching management information construction.

\section{Conclusion}

Under the background that the whole school running scale is very large, it is very important how to promote the level of teaching management and the level of teaching management through effective teaching management information construction. This study firstly, through the theoretical analysis, elaborates the theory foundation of university teaching management information, and then sorts out the concept and connotation of the university teaching management information. Then the current situation of the construction of teaching management information in Colleges and universities in China is summarized, and five main problems existing in our current College teaching management information are analyzed, namely deviation of the idea understanding, lack of material conditions of deposit guarantees and extensive participation, and passable effect of the system. And eventually countermeasures to improve the construction of teaching management information in our Colleges and universities are put forward: strengthen the understanding of the great significance of teaching management information; improve the construction of information organization construction, and highlight the top-level design; and improve the teaching management information supporting system.

\section{References}

[1] Pan G. Research on the Construction of Digital Campus Based on Informationization of Teaching Management [J]. Science Mosaic, 2014, 1: 010.

[2] Sousa K J, Oz E. Management information systems [M]. Nelson Education, 2014.

[3] Yan Z. Asymmetric information problems and solutions in the teaching management for secondary colleges in universities [J]. Journal of Jiamusi Vocational Institute, 2015, 7: 137.

[4] Galliers R D, Leidner D E. Strategic information management: challenges and strategies in managing information systems [M]. Routledge, 2014.

[5] Fewings P. Construction project management: An integrated approach [M]. Routledge, 2013. 